\title{
Study the Inhibitory Effect of Mustard Seed Powder on the Growth of Sclerotium rolfsii
}

\author{
T. Yella Goud*, G. Uma Devi, P. Narayan Reddy and A. Siva Sankar \\ Department of Plant Pathology, College of Agriculture, Rajendranagar, Acharya N G Ranga \\ Agricultural University, Hyderabad 500 030, Andhra Pradesh, India \\ *Corresponding author
}

\section{A B S T R A C T}

\begin{tabular}{|l|}
\hline Ke y w or d s \\
$\begin{array}{l}\text { Sclerotium rolfsii, } \\
\text { Mustard seed } \\
\text { powder, Mycelial } \\
\text { growth. }\end{array}$ \\
\hline Article Info \\
\hline $\begin{array}{l}\text { Accepted: } \\
\text { 21 September } 2017 \\
\text { Available Online: } \\
\text { 10 October 2017 }\end{array}$ \\
\hline
\end{tabular}

Stem and Pod rot caused by Sclerotium rolfsii is one of the major constraint affecting the seed and oil production in groundnut growing areas of the world. An attempt was made to manage the disease by holistic approach. In vitro evaluation of different concentrations of mustard was conducted using two types of methods; (a) Continuously exposing to single MSP and (b) fresh MSP was replenished every 24 hours. Cent per cent inhibition of $S$. rolfsii was observed at 100 and 200 $\mathrm{mg}$ of MSP in both the methods. But, $50 \mathrm{mg}$ concentration was also inhibited growth of $S$. rolfsii up to $93.10 \%$ after 72 hours over the control. The test concentrations in this experiment successfully inhibited the growth of $S$. rolfsii. Hence it is necessary that these treatments be tested under field conditions before they can be exploited in a commercial set up.

\section{Introduction}

Groundnut (Arachis hypogaea L.) is also known as peanut, is a legume that ranks 6th among the oilseed crops and 13th among the food crops of the world (Icrisat, 2017). Groundnut is grown on nearly 4.76 million ha in India with the total production of 7.40 million tonnes and an average yield of 1552 $\mathrm{kg} / \mathrm{ha}$ in 2014-15 (India Stat, 2017). China, India, Nigeria, USA and Myanmar are the major groundnut growing countries. Developing countries in Asia, Africa and South America account for over $97 \%$ of world groundnut area and $95 \%$ of total production (Icrisat, 2017). The crop suffers with many fungal, bacterial and viral diseases resulting in huge yield losses. Among the fungal diseases, stem and rot or Southern blight disease caused by Sclerotium rolfsii is one of the major concern and causing the economic losses in Groundnut (Deepthi and Reddy, 2013).

Sclerotium rolfsii, a deuteromycetous soil borne facultative parasitic fungi having extensive host range which causes preemergence rot, collar rot, stem rot or wilt in at least 500 species in 100 families and the most common hosts are the legumes, crucifers, and cucurbits (Aycock, 1966; Domsch et al., 1980; Farr et al., 1989). Worldwide the groundnut yield loss due to stem rot is 25 to 90 percent and the control of the disease was not achieved (Grichar and Bosweel, 1987; Adiver 
2003; Rodriguez Kabana et al., 1975). But the management of disease by using chemical fungicides and synthetic plant growth regulators are very expensive and disturb the ecosystem and will not provide complete protection from the pathogen. The long term effect were overlooked hence, boom of one time become bane for the ecosystem degradation. At the present context, it has become indispensable to look for sustainable crop protection management approaches for disease management and the present work is an effort to this direction.

A crucial factor in the management of diseases caused by these pathogens is to reduce their inoculum level below the critical threshold level before a susceptible crop is planted. Since the 1950s, chemical soil disinfestations have commonly been used for this purpose. Soil fumigants, especially Methyl Bromide (MB) is the most effective soil fumigant used by farmers around the world for this purpose. Today, there is the need for diversified options and alternatives to fill different roles across the soil borne pest and disease management spectrum. Apart from various synthetic chemical alternatives, numerous nonchemical tactics have also been explored, field authenticated and in some cases implemented commercially. For certain situations, biofumigation and soil solarization are among the most useful of the nonchemical disinfestations methods (Prasad et al., 2015). There is worldwide acceptance to the use of ecologically safe, environment friendly methods of protecting crops from the plant pathogens. Glucosinolates compounds that occur in agronomically important crops may represent a viable source of allelochemical for the control of various soil borne pests (Angus, et al., 1994). Brassica species contain glucosinolates (GSL), which, upon tissue disruption, are hydrolyzed in the presence of water by an endogenous myrosinase enzyme into numerous compounds, notably toxic isothiocynates (ITC). Insecticidal, nematicidal, fungicidal and phytotoxic effects are often associated with tissues of cruciferous and Brassica plants. The detrimental effect of pure ITC to certain fungi has long been known and the potential of Brassica crops to control soil borne pests and pathogens mainly attributed to these compounds. This process is termed as "bio-fumigation" (Angus, et al., 1994).

\section{Materials and Methods}

\section{Isolation and maintenance of pathogen}

Groundnut (Arachis hypogaea L.) plants showing stem rot symptoms were collected from Regional agriculture research station (RARS) Kadiri, Anathapur district of Andhra Pradesh, India. Infected stem tissues were surface sterilized with $0.1 \% \mathrm{HgCl}_{2}$ (1 g/lit) for 1 miunte followed by three subsequent washing with sterilized distilled water in aseptic condition. The sterilized pieces were then transferred aseptically under laminar airflow on sterilized Petri plates containing 20 $\mathrm{ml}$ potato dextrose Agar (PDA) medium. The Petri plates were incubated in biological oxygen demand (BOD) at $28 \pm 2^{\circ} \mathrm{C}$ temperature for optimum growth. The fungal hyphae developing from the infected tissues were sub-cultured aseptically on PDA media containing in Petri plates. Thus, pure culture was obtained by hyphal tip method and microscopically examined for identification and it was further purified by using single sclerotial body. The culture was maintained on PDA slants for further investigations.

Identification of the pathogen causing stem rot of groundnut was carried out by studying the cultural and morphological characters were recorded right from initiation of mycelial growth till the period of 15 days. The morphological characters viz., mycelia growth and sclerotial formation, its size, 
shape and colour were studied under low power magnification (10X) from 10 days old culture of $S$. rolfsii and were compared with identification key described in "Illustrated Genera of Imperfect Fungi" (Barnett and Hunter, 1998). The pathogenicity test of the pathogen was also carried out in pots by stem inoculation technique as described (Patil et al., 1977).

An experiment was carried out under in vitro conditions with minor modification of the procedure of Rahmanpour et al., (2009) in two different methods. Mustard seed powder (MSP) was prepared using pestle and mortar with commercially available mustard seeds just before the experiment.

\section{Method (a)}

In this method different amounts of MSP viz., 20, 50, 100 and $200 \mathrm{mg}$ MSP was added in the aluminum foil which was kept in the upper lid of the Petri plate. In order to hydrolyze the glucosinolates (GSLs), sterile distilled water $\left(10 \mu \mathrm{L} \mathrm{mg}^{-1}\right)$ was added to the MSP. Twenty ml of PDA medium was poured in $90 \mathrm{~mm}(4.50 \mathrm{~cm})$ sterilized Petri plates and allowed to solidify. Mycelial disc of $5 \mathrm{~cm}$ from three day old culture of the pathogen $S$. rolfsii was inoculated at the center of the Petri plate. The base of the Petri plate was placed on the top of the upturned lid, which contained the MSP. Petri plates without MSP served as control. The plates were incubated at $28 \pm 2{ }^{\circ} \mathrm{C}$ for 5 days.

\section{Method (b)}

In another method the fungal cultures was exposed to volatiles for 5 days by replacing fresh MSP every 24 hours also similarly without replacement of MSP which was initially kept in the aluminum foils. Six replications were maintained for each treatment. The data for the growth of $S$. rolfsii was measured at 24, 48, 60, 72 and 96 hours and per cent inhibition of mycelial growth calculated using the following formula (Vincent, 1927).

The per cent inhibition was measured using the formula:

$I=\frac{C-T}{C}$

Where,

$\mathrm{I}=$ Per cent inhibition of mycelial growth, $\mathrm{C}=$ Colony diameter in control $(\mathrm{cm})$, $\mathrm{T}=$ Colony diameter treatment $(\mathrm{cm})$

\section{Results and Discussion}

In the present experiment all the concentrations of MSP tested were significantly effective in inhibiting the mycelial growth of $S$. rolfsii.

In both the methods at $100 \mathrm{mg}$ and $200 \mathrm{mg}$ concentrations 100 per cent growth of $S$. rolfsii was inhibited. But also growth of $S$. rolfsii was not detected at all the concentrations tested in both the methods at 24 hours after incubation whereas control plates shown the growth of $0.72 \mathrm{~cm}$ radial growth at same incubation period.

Whereas in method (b) at 48, 72 and 96 hours there was 78.9 to 84.75 per cent, 81.1 to 88.30 per cent and 55 to 90.10 per cent inhibition observed when the MSP was increased from 20 to $50 \mathrm{mg}$ was maintained with the fungal cultures were exposed to volatiles for 5 days with replacement of fresh MSP every 24 hours when 20 and $50 \mathrm{mg}$ were used respectively. A highest inhibition of 90 per cent was observed after 96 hours when $50 \mathrm{mg}$ concentration MSP was used in method (b) results are represented in table I. 
However the growth of $S$. rolfsii was more when the MSP was not replaced every day. Whereas in method (a) maintained without replacement of MSP which was initially kept in the aluminum foils for five days the growth of $S$. rolfsii was more compare to exposure to the fresh MSP for every 24 hours. The results obtain in this at 20 and $50 \mathrm{mg}$ concentration are 53.00, 73.00 per cent inhibition, 23.14, 41.70 per cent inhibition, 31.52, 23.00 per cent inhibition at 48, 72 and 96 hours of exposure results are presented in table II. The growth observed was up to $2.20 \mathrm{~cm}(23 \%)$ in $50 \mathrm{mg}$ MSP used treatment at the end (96 hours) of the experiment. Both the experiments gave complete inhibition in growth of $S$. rolfsii at 100 and $200 \mathrm{mg}$ concentration of MSP.

Studies of Rahamanpour et al., (2009) showed that the growth rate of the fungal colony Sclerotinia sclerotiorum over 5 days was significantly inhibited initially, rates recovered to reach those of the control over a 2 to 4 day period, depending on the amount of MSP supplied. All the treatments with MSP had statistically similar growth rates 72 hours after application.

Table.1 Bio-assay of volatiles released from MSP replaced with fresh MSP every 24 hour interval

\begin{tabular}{|c|c|c|c|c|c|}
\hline \multirow[t]{2}{*}{ Time duration } & \multicolumn{5}{|c|}{ MSP Concentration Radial growth of $S$. rolfsii $(\mathrm{cm})$} \\
\hline & $20 \mathrm{mg}$ & $50 \mathrm{mg}$ & $100 \mathrm{mg}$ & $200 \mathrm{mg}$ & Control \\
\hline \multirow[t]{2}{*}{24 Hours } & - & - & - & - & 0.72 \\
\hline & $(100)^{*}$ & $(100)$ & $(100)$ & $(100)$ & -- \\
\hline \multirow[t]{2}{*}{48 Hours } & 0.47 & 0.34 & 0.0 & 0.0 & 2.23 \\
\hline & $(78.90)$ & $(84.75)$ & (100) & (100) & -- \\
\hline \multirow[t]{2}{*}{72 Hours } & 0.66 & 0.41 & 0.0 & 0.0 & 3.50 \\
\hline & $(81.10)$ & $(88.30)$ & (100) & (100) & -- \\
\hline \multirow[t]{2}{*}{96 Hours } & 1.9 & 0.42 & 0.0 & 0.0 & 4.25 \\
\hline & $(55.00)$ & $(90.10)$ & $(100)$ & $(100)$ & -- \\
\hline SEm & \multicolumn{5}{|c|}{$\mathrm{CD}$ at $5 \%$} \\
\hline & 032 & \multicolumn{4}{|c|}{0.064} \\
\hline $\mathrm{F}_{2}$ & 036 & \multicolumn{4}{|c|}{0.071} \\
\hline $\mathrm{F}_{1} \times \mathrm{F}_{2}=$ & 073 & & & & \\
\hline
\end{tabular}

* Figures in parenthesis are per cent inhibition over control

Table.2 Bio-assay of volatiles released from MSP

\begin{tabular}{|c|c|c|c|c|c|}
\hline \multirow[t]{2}{*}{ Time duration } & \multicolumn{5}{|c|}{ MSP Concentration Radial growth of S. rolfsii (cm) } \\
\hline & $20 \mathrm{mg}$ & $50 \mathrm{mg}$ & $100 \mathrm{mg}$ & $200 \mathrm{mg}$ & Control \\
\hline \multirow[t]{2}{*}{24 Hours } & - & - & - & - & 0.72 \\
\hline & (100) & $(100)$ & $(100)$ & $(100)$ & -- \\
\hline \multirow[t]{2}{*}{48 Hours } & 1.05 & 0.60 & 0.00 & 0.00 & 2.23 \\
\hline & $(53.00)$ & $(73.00)$ & $(100)$ & $(100)$ & -- \\
\hline \multirow[t]{2}{*}{72 Hours } & 2.69 & 2.04 & 0.0 & 0.0 & 3.50 \\
\hline & (23.14) & $(41.71)$ & $(100)$ & (100) & -- \\
\hline \multirow[t]{2}{*}{96 Hours } & 2.91 & 2.20 & 0.0 & 0.0 & 4.25 \\
\hline & $(31.52)$ & $(48.23)$ & $(100)$ & $(100)$ & -- \\
\hline \multicolumn{6}{|l|}{ SEm \pm} \\
\hline & 0.056 & 0.110 & & & \\
\hline $\mathrm{F}_{2}$ & 0.063 & 0.123 & & & \\
\hline$F_{1} \times F_{2}=$ & 0.126 & 0.247 & & & \\
\hline
\end{tabular}

* Figures in parenthesis are per cent inhibition over control 
The effect of mustard seed meal on linear growth of soybean root-rot and wilt fungal pathogens was observed by Fayzalla et al., (2009). Mustard seed meal proved to be effective for controlling the pathogen and resulted in decreasing the linear growth of the pathogen Rhizoctonia solani at all levels (5, 10 and $25 \mathrm{mg}$ plate $\left.^{-1}\right)$ as compared with the control. The results are in conformity with those of Noble et al., (2002). Seed meal of Brassica species suppresses the growth of Pythium ultimum, Rhizoctonia solani (Charan and Sams (1999)) and Fusarium sambucinum (Mayton et al., 1996). Chung et al., (2002) proved that the volatile substances in the ground seed of mustard showed the strongest fungicidal effect on $R$. solani through comparing three Brassica species for volatile compounds in hydrated ground seeds. Kirkegaard et al., (2006) reported that seed meal of mustard was fungicidal to five soil borne pathogens. Further, Robert Larkin and Griffin (2007) also found that in vitro assays of Indian mustard resulted in nearly complete inhibition (80-100\%) of growth of soil borne pathogens of potato, including Rhizoctonia solani, Phytophthora erythrospetica, Pythium ultimum, Sclerotinia sclerotiorum and Fusarium sambucinum which are in agreement with our results.

Smolinska et al., (1997) conducted experiment with the seed meal of Brassica napus (rapeseed) which produced volatile fungi-toxic compounds potentially of value in the control of Aphanomyces root rot of pea. These compounds were extremely effective in the suppression of encysted zoospore germination.

In the present investigation although the volatiles produced from brassica leaf tissue were inhibitory to $S$. rolfsii, colonization of the plant material continued to progress over $48 \mathrm{~h}$, suggesting that the fungus may have the ability to adapt to volatiles. Despite evidence for production of volatiles as well as their ability to inhibit fungal growth in a bioassay, the pathogen $S$. rolfsii continued to grow in the leaf discs suggesting that it may have a mechanism for overcoming toxicity of volatiles produced
(Goud et al., 2011). Results of volatiles released from MSP showed that the growth of the pathogen was completely inhibited initially at 24 hours, but due to continuous exposure to toxic volatiles, initial inhibition was followed by adaptation and recovery of growth to control level suggesting that the fungus may have the ability to adapt to volatiles at lower concentrations.

Adaption of $S$. rolfsii to the exposure of MSP continuously for five days with replacement of fresh MSP at 24 hours interval showed effective results with the replacement of MSP for five days at low concentrations 20 and $50 \mathrm{mg}$. The concentrations 100 and $200 \mathrm{mg}$ inhibited the fungus growth absolutely. However, these studies showed that the exposure of the pathogen S. rolfsii to the MSP volatiles to 100 mg concentration and more inhibited the growth under in vitro conditions. Future research should focus on determining the effects of MSP under field conditions.

\section{References}

Adiver, S.S., 2003. Influence of Organic Amendments and Biological Components on Stem Rot of Groundnu, National Seminar on Stress Management in Oilseeds For Attaining Self Reliance in Vegetable Oil Indian Society of Oilseeds Research, Directorate of Oilseeds Research, Hyderabad Form January 28 30: 15-17.

Aneja, K.R., 2007. Experiments in Microbiology, Plant pathology and Biotechnology. 348.

Angus, J.F., Gardner, P.A., Kirkegaard, J.A and Desmarchelier, J.M. 1994. Biofumigation: Isothiocynates released from Brassica roots inhibit growth of the take-all fungus. Plant and Soil. 162: 107112.

Aycock, R., 1966. Stem Rots and Other Disease Caused by Sclerotium rolfsii North Carolina, Agricultural Experiment Station Technical Bulletin. No. 174: 202.

Barnett, H.L., and Hunter, BB. 1998. Illustrated 
genera of imperfect fungi. ( $4^{\text {th }}$ edn.) Published by Am Phytolo Soci. 196.

Charan, C.S., and Sams, S.E. 1999. Inhibition of Pythium ultimum and Rhizoctonia solani by shredded leaves of Brassica species. J. Am. Soc. Hort. Sci. 124: 462467.

Chung, W.C., Huang, H.C., Huang and Jen, J.F. 2002. Effect of ground Brassica seed meal on control of Rhizoctonia dampingoff of cabbage. Canadian Journal of Plant Pathology. 24: 211-218.

Deepthi, K. C., and Eswara Reddy, N. P. 2013. Stem rot disease of groundnut (Arachis hypogaea L.) induced by Sclerotium rolfsii and its management. 2 (3): 26-38.

Domsch, K. H., 1980. Compendium of Soil Fungi, Academic Press, London.

Farr, D. F., Bills, G.F., Chamuris, G. P and Rossman, A. Y. 1989. Fungi on Plants and Plant Products in the United States. American phytopathology Society. 1252.

Fayzalla, E. A., El-Barougy, E and El-Rayes, M. M. 2009. Control of soil-borne pathogenic fungi of soybean by Biofumigation with Mustard seed meal. Journal of Applied Sciences. 9 (12): 2272-2279.

Grichar, V. J., and Bosweel, T. E 1987. Comparison of Lorsban and Tilt with Terrachlor for Control of Southern Blight on Peanut the Texas. Agriculture Experiment Station. 4534.

Kirkegaard, J.A., and Matthiessen, J.N. 2006. Biofumigation and enhanced biodegradation: opportunity and challenge in soil borne pest and disease management. Critical Reviews in Plant Sciences 25: 235-65.

Mayton, H.S., Oliver, C., Vaughn, S.F and Loria, R. 1996. Correlation of fungicidal activity of Brassica species with allyl isothiocyanate production in macerated leaf tissue. Phytopathology. 86: 267-271.

Noble, R.R.P., Harvey, S.G and Sams, C.E. 2002. Toxicity of Indian mustard and allyl isothiocynate to masked chafer beetle larvae. Online. Plant Health progress doi: 10.1094/PHP-2002-061001-RS.

Patil, M.B., Patil, G.D and Wani, P.V. 1977. Varietal reaction of groundnut against Sclerotium rolfsii. Indian phytopath 30: 562.

Prasad, P., Kumar, J. and Pandey. S. 2015. Biofumigation: Success and Prospects in Soilborne Plant Disease Management. International Journal of Applied and Pure Science and Agriculture. 1(6): 47-59.

Rahmanpour, S., Backhouse, D and Nonhebel, H.M. 2009. Induced tolerance of Sclerotinia sclerotiorum to isothiocynates and toxic volatiles from Brassica species. Plant Pathology. 58: 479-486.

Robert Larkin, P., and Griffin, T.S. 2007. Control of soil borne potato diseases using Brassica green manures. Crop Protection. 26: 1067-1077.

Rodriguez-kabana, R., Backman, P. A and Williams, J. C. 1975. Determination of Yield Losses Due to Sclerotium Rolfsii in Peanut Fields. Plant Dis Rept. 59: 855858.

Smolinska, U., Knudsen, G.R., Morra, M.J and Borek, V. 1997. Inhibition of Aphanomyces euteiches f. sp. pisi by volatiles produced by hydrolysis of Brassica napus seed meal. Plant disease. 81: 288-292.

Vincent, J.M., 1927. Distortion of fungal hyphae in the presence of certain inhibitors. Nature 59: 850.

Yella Goud, T., Uma Devi, G., Narayan Reddy, $\mathrm{P}$ and Siva Sankar. A. 2011. Indian Journal of Plant Protection. 39(4): 304.

\section{How to cite this article:}

Yella Goud, T., G. Uma Devi, P. Narayan Reddy and Siva Sankar, A. 2017. Study the Inhibitory Effect of Mustard Seed Powder on the Growth of Sclerotium rolfsii. Int.J.Curr.Microbiol.App.Sci. 6(10): 24382443. doi: : https://doi.org/10.20546/ijcmas.2017.610.288 